\section{INDUSTRIAL INJURIES IN WAR-TIME}

\section{A} REPORT by Prof. H. Levy on "War and Industrial Injuries" which has been issued by the Fabian Society (Tract Series No. 253) emphasizes the importance in the war effort of the fitness of the army of industrial workers behind the soldier, and directs attention to the cost of industrial accidents not only in sums paid for compensation but also in the loss of working time, both direct and indirect. In present circumstances it is emphasized that we must use to the full every ounce of man-power we possess that can be employed on production and that the present arrangements for preventing accidents and still more for the treatment of injuries and of industrial disease result in a very great and unnecessary waste of man-power-a wastage which is likely to be enormously increased under war conditions.

Prof. Levy therefore urges that one of the most important single contributions to the war effort would be the immediate introduction of expedients designed both to minimize the occurrence of accidents and to improve the facilities for treating the injuries resulting from them. The proposals put forward are essentially intended for the consideration of the Royal Commission on Workmen's Compensation, as any final solution involves drastic reform both of the law of workmen's compensation and the system of National Health Insurance. The main purpose, however, of any immediate proposals should be to create throughout the industry af this country institutions charged with the continuous and positive duty of preventing accidents so far as possible, and, where accidents occur, of providing for rapid and effective treatment of the victim. The changes now being made in factory administration, and the establishment under the chairmanship of Mr. Ernest Bevin of a new Factory and Welfare Advisory Board, provide a unique opportunity to use the new powers of the Ministry of Labour to extend and develop this type of organization over the whole of industry.

With regard to organization, the essential is that for a well-established industry of any size those who are vitally concerned in the running of the industry and who understand its problems should be entrusted with the task of preserving its man-power. Where joint standing committees do not exist, associations of employers and employees should be asked to form committees and compulsion brought to bear if this is not done voluntarily within a limited period of time. For small, scattered or ill-organized industries or occupations the Ministry should itself set up a welfare and safety organization partly of official members and partly of representatives of those engaged in the trade or occupation. To function effectively, such committees must be given really wide powers, including the right to visit any plant in the industry with which they are concerned, to inspect its safety provisions, make additional suggestions and under prescribed regulations inflict fines for the nonobservance of safety provisions. The committees should be under an obligation to provide medical treatment for injured workers where the injury is serious, the treatment to be arranged so as not to interfere with existing arrangements, which at present are sketchy and inadequate. The committee would also be able to arrange far more efficiently than any centralized board for special attention to the particular problems of its own industry.

\section{APPOINTMENTS VACANT}

APPIICATIONS are invited for the following appointments on or before the dates mentioned : SUPERvisor of Domrstic Scinnce Training in Jamaica-The
Secretary (I.P.R.), Board of Education, Kingsway, W.C.2 (August 26). Profkssor of GeOgRAPHY at the Higher Teachers' College, Baghdad-The Secretary (I.P.R.), Board of Education, Kingsway, W.C.2 (August 26).

TEAOHER (MAN) OF ENGINEERING SUBJEOTS in the South Dorset Technical College, Weymouth-The County Education Officer, County Education Office, Colliton House, Dorchester, Dorset (August 26).

Professor of HOME ScIENCE in the University of Otago-The High Commissioner for New Zealand, 415 Strand, W.C.2 (August 31).

LECTURER IN BIOchamistry in University College, Dundee-The Secretary, The University, St. Andrews (August 31).

Grade II (c) Lecturer in the Department of Mechanical ENGINERRING-The Secretary, The University, Birmingham 3 (August 31).

\section{REPORTS AND OTHER PUBLICATIONS \\ (not included in the monthly Boaks Supplement)}

\section{Great Britain and Ireland}

University of Reading : National Institute for Research in Dairying. Annul Report for the Year ending 30th September 1939. Pp. 90. Annual Report for the Year ending 30th September 1939. Pp. 90.
(Reading: National Institute for Research in Dairying.) Experimental Researches and Reports published by the Department of Glass Technotogy, The University, Sheffleld. Vol. 22, 1939. Pp. ili +
248. (Sheffeld : The University.) 78. 6d.

Witherite (Natural Barium Carbonate) and its Industrial Uses. Issued jointly by the Holmside and South Moor Collieries, Ltd., and the Owners of Settlingstones Mines, Ltd. Pp. 56. (Stanley, Co.
Durham : Holmside and South Moor Collieries, Ltd.)

\section{Other Countries}

Proceedings of the United States National Museum. Vol. 88, No. 3091: A Prehistoric Roulette from Wyandotte County, Kansas. By Waldo $R$. Wedel and Harry M. Trowbridge. Pp. 581-586. Vol. 89, No. 3092: A Revision of the West. Indian Beetles of the Scarabaeid Sub-family Aphodiinae. By Edward A. Chapin. Pp. 42. (Washing-
ton, D.C.: Government Printing Office.)

Newfoundland Government. Research Bulletin No. 8: Lobster Tagging on the West Coast of Newfoundland, 1938. Dr. Dr. W. Temple-

Madras Fisheries Department. Fish Statistics for 1928-29, 1929-30 and 1930-31. Edited by Dr. B. Sundara Raj. (Reports 2, 3 and 4 of and 1930-31. Edited by Dr. B. Sundara Raj. (Reports 2, 3 and 4 of 1937, Madras Fisheries Bulletin, Vol. 27.) Pp. iv +71-264. (Madras :
Government Press.) 2.14 rupees.

India Meteorological Department. Scientific Notes, Vol. 8, No. 88 : A Historical Note on the Standard for the Measurement of Atmospheric Pressure in India. By J. M. Sil. Pp. 47-66. (Delh1: Manager of Publications.) 10 annas; 18.

Proceedings of the American Academy of Arts and Sciences, Vol. 73. No. 11: Interatomic Forces and Helium in Rocks. By Norman B. Keevil. Pp. 311-360. 1.50 dollars. Vol. 73, No. 12: Some Physica Constants of a Few Hydrocarbons and their Structural Isomers. By Mieczyslaw Wojciechowski. Pp. 361-370. 35 cents. (Boston, Mass. :
American Academy of Arts and Sciences.) Astrographic Catalogue 1900.0. Sydney Section, Dec. $-51^{\circ}$ to - From Photographs taken at the Sydney Observatory, New Pouth Wales, Australia. Vontres Dec, -57. Pp. 98. (Sydney : Government Printer.) [ 317 De Tuberculine Reactie. Door Injo Beng Liong. Pp. viii +203. (Batavia: Medical College.)

Instituto Nacional de Tecnologia (Ministerio do Trabalho, Industria Comercio) Fstudos sobre o tratamento de agua por coagulaca. Por Eros Orosco, E. Frias Rocha e E. Goulart de Andrade. Pp. 28 Gordura de Batí: considerações para o estudo do problema da oblenç\%。 em bases industriais. Pelo Jayme Sta. Rosa. Pp. 26. Papoula de em bases industriais. Pelo Jayme Sta. Rosa. Pp. 26. Papoula de Såo Francisco. Pelo Waimir A. Teixeira de Carvalho. Pp. 48. Metrologia (métodos óticos nas medidas de comprimento de alta precisão) Pelo J. Costa Ribiero. Pp. $28+4$ plates. A Mandioca : sua industrialzação, seu valor econômico. Pelos Ruben Descartes de G. Paula e José Luiz Rangel. Pp. $60+4$ plates. (Rio de Janeiro: Instituto Naciona]
de Tenologia.) Commonwealth of Australia : Council for Scientific and Industrial Research. Pamphlet No.96: Further Investigations on Copper Deficiency in Plants in South Africa. By D. S. Riceman, C. M. Donald and S. T. Evans. Pp. $44+10$ plates. (Melbourne: Government Printer.) liminary Study of Newfoundland Trout. By Nancy Frost. Pp. 30 (St. John's: Department of Natural Resources.)

Catalogues

Rapid Testing applied to Foods, Chemicals, etc., in Industrial and Scientiflc Research, by Fluorescence with the Hanovia Analytic Lamp. Pp. 20. (Slough : Hanovia, Ltd.)

Chemicals, Reagents. (Catalogue No. 65CR.) Pp. 64. Wade

A Catalogue of Important Books, including Americana, English Literature, Music, Ornithologv, and Important New Books. (No.578.) Pp. 40. (London: Bernard Quaritch, Ltd.). 